\title{
A note on the performance of crossbred lambs fed a concentrate mixture containing a high level of double improved rapeseed oilmeal
}

\author{
A. Baranowski and J. Klewiec \\ The Institute of Animal Genetics and Breeding, Polish Academy of Sciences \\ Jastrzębiec, 05-551 Mroków, Poland
}

(Reccived 2 April 1999; accepted 5 July 1999)

\section{ABSTRACT}

Two groups ( $\mathrm{n}=30$ ) of crossbred lambs ( $25 \%$ Polish Merino, $25 \%$ Booroola and $50 \%$ Suffolk) were intensively fattened from the age of 8 wecks until reaching a body weight of $35 \mathrm{~kg}$. Group II received a pelleted concentrate containing $207 \mathrm{~g}$ of cride protein (CP) $/ \mathrm{kg}$ of dry matter (DM) and 12.5 $\mathrm{MJ}$ of metabolizable energy (ME) $/ \mathrm{kg}$ DM and group I was fed a concentrate with a similar nutritional value (202 $\mathrm{g} \mathrm{CP} / \mathrm{kg}$ DM and $12.7 \mathrm{MJ} \mathrm{ME} / \mathrm{kg}$ DM) but soyabcan oilmeal and dried sugar beet pulp were substituted by solvent-extracted rapeseed oilmeal ( $25 \%$ in mixture) and oats, respectively. Lambs of both groups consumed a similar quantity of DM, CP and ME (respectively $85 \mathrm{~g}, 17 \mathrm{~g}$ and $1.1 \mathrm{MJ} / \mathrm{kg}$ $\mathrm{W}^{0.75}$ and $77 \mathrm{~g}, 16 \mathrm{~g}$ and $1.0 \mathrm{MJ} / \mathrm{kg} \mathrm{W}^{1.75}$ for group 1 and $\mathrm{II}$ ), irrespective of the type of concentrate offered. Daily weight gains of lambs from group I $(290 \mathrm{~g})$ were lower $(\mathrm{P}<0.05)$ than those of lambs from group II $(325 \mathrm{~g})$. No significant differences between groups were observed in the intake of CP or ME per kg of weight gain (group I -- $649 \mathrm{~g}$ and $40.8 \mathrm{MJ}$ and group II $-595 \mathrm{~g}$ and $35.9 \mathrm{MJ}$ ). The cost of concentrate used for the production of $1 \mathrm{~kg}$ of liveweight was similar in both groups

KEY WORDS: lambs, fattening performance, rapeseed oilmeal

\section{INTRODUCTION}

Solvent extracted rapeseed oilmeal obtained from double improved rapeseed is a valuable feed due to its high protein content and favourable amino acid composition (Gwiazda et al., 1996). However, the comparatively high content of crude fibre and the presence of antinutritional components in rapeseed oilmeal (Sionek 
et al., 1994; Gwiazda et al., 1996) restricts its use as a substitute for soyabcan oilmeal in concentrates designated for suckling lambs (Potkański et al., 1991; Urbaniak and Potkański, 1991). The results of other investigations (Potkański et al., 1987 a,b; Pakulski and Osikowski, 1993) point to the possibility of total replacement of soyabean oilmeal with rapesecd oilmeal in concentrates for older lambs, weaned at the age of 3 or 4 months and fattened to a liveweight of $40-45 \mathrm{~kg}$. However, there is insufficient information on the use of solvent-extracted rapeseed oilmeal as the main protein source in concentrates for the intensive fattening of young lambs. On the other hand, substituting soyabean oilmeal with rapeseed oilmeal markedly decreases the cost of concentrates. This problem is gaining importance since the meat utilization of sheep directed at the production of slaughter lambs is steadily increasing in Poland.

The present work was aimed at determining the production results of growing crossbred lambs, intensively fattened on a concentrate in which, in order to lower feed price, soyabean oilmcal and dried sugar beet pulp were substituted by solvent extracted rapeseed oilmeal and oats, respectively.

\section{MATERIAL AND METHODS}

The experiment was conducted on 30 crossbred lambs (25\% Merino, $25 \%$ Booroola and $50 \%$ Suffolk) born in twin $(n=9)$, triple $(n=10)$ and quadruple $(n=11)$ litters. After weaning at the age of 8 weeks the lambs were kept in individual pens and fattened intensively until reaching a liveweight of $35 \mathrm{~kg}( \pm 1 \mathrm{~kg})$. During the fattening period the lambs were allocated to groups by similar liveweight, age and type of birth ( 8 rams and 7 ewes in each group) and were fed ad libitum a pelleted $(0.5 \mathrm{~cm})$ concentrate (Table 1$)$ in which rapeseed oilmeal obtaincd from double

TABLE 1

Composition of concentrates, \%

\begin{tabular}{lrr}
\hline & \multicolumn{2}{c}{ Concentrate mixture } \\
\cline { 2 - 3 } Ingredient & $\mathrm{I}$ & II \\
\hline Rapesced oilmeal & 25.0 & 0 \\
Soyabean oilmeal & 0 & 17.0 \\
Ground field bean & 10.0 & 13.0 \\
Ground barley & 44.1 & 47.0 \\
Ground oats & 17.0 & 10.0 \\
Dricd sugar beet pulp & 0 & 9.1 \\
Mincrals & 2.9 & 2.9 \\
Beet molasses & 1.0 & 1.0 \\
Price of concentrate, \% & 100 & 110 \\
\hline
\end{tabular}


improved rapeseed (Group I) or soyabean oilmeal (Group II) constituted the main source of protein. In order to ensure proper rumen function, the lambs additionally received about $100 \mathrm{~g}$ of hay/day (not recorded), which they did not consume in full. During the fattening period the quantities of concentrates consumed were recorded individually.

The proximate analysis of feeds was performed using standard methods. The metabolizable energy of fecds was calculated on the basis of the results of chemical analysis using the equation proposed by MAFF (1975). The results obtained were elaborated statistically using analysis of variance (Harvey, 1990).

\section{RESULTS}

Concentrates fed to both groups (Table 2) had a similar content of crude protein (202 $\mathrm{g}$ and $207 \mathrm{~g} / \mathrm{kg} \mathrm{DM}$ for groups I and II, respectively) and ME (12.7 MJ and $12.5 \mathrm{MJ} / \mathrm{kg} \mathrm{DM}$ for group I and II respectively). The concentrate containing rapeseed oilmeal had a higher content of crude fibre and ether extract $(78$ and $52 \mathrm{~g} / \mathrm{kg}$ $\mathrm{DM}$, respectively) than that composed of soyabean oilmeal $(65$ and $17 \mathrm{~g} / \mathrm{kg} \mathrm{DM}$, respectively). The acid detergent lignin content was twice as high in the concentrate containing rapeseed oilmeal (37 vs $16 \mathrm{~g} / \mathrm{kg} \mathrm{DM}$ ). Calculated per metabolic body weight $\left(\mathrm{W}^{0.75}\right.$ ), consumption of DM of both concentrates (Table 3 ) was similar ( $85 \mathrm{vs} 77 \mathrm{~g}$ ). Also, there were no significant differences between groups in the consumption of $\mathrm{CP}$ (17 vs $16 \mathrm{~g}$ ) and $\mathrm{ME}$ (1.1 MJ vs $1.0 \mathrm{MJ})$. However, lambs receiving the concentrate with rapeseed oilmeal (group I) consumed significantly $(\mathrm{P}<0.01)$ more crude fibre and ether extract ( 7 and $5 \mathrm{~g}$, respectively) than did

TABLE 2

Chemical composition ( $\mathrm{g} / \mathrm{kg} \mathrm{DM}$ ) and energy value (MJ/kg DM) of feeds

\begin{tabular}{|c|c|c|c|}
\hline \multirow[b]{2}{*}{ Item } & \multicolumn{2}{|c|}{ Concentrate mixture } & \multirow{2}{*}{$\begin{array}{c}\text { Meadow } \\
\text { hay }\end{array}$} \\
\hline & I & II & \\
\hline Dry matter, g/kg & 873 & 869 & 857 \\
\hline Organic matter & 922 & 943 & 933 \\
\hline Crude ash & 78 & 57 & 67 \\
\hline Crude protein & 202 & 207 & 122 \\
\hline Crude fibre & 78 & 65 & 312 \\
\hline Ether exiract & 52 & 17 & 19 \\
\hline $\mathrm{N}$-free extractives & 590 & 654 & 480 \\
\hline NDF & 208 & 201 & 632 \\
\hline $\mathrm{ADF}$ & 111 & 87 & 355 \\
\hline $\mathrm{ADL}$ & 37 & 16 & 43 \\
\hline Metabolizable energy, MJ & 12.7 & 12.5 & 10.3 \\
\hline
\end{tabular}


animals fed the concentrate containing soyabean oilmeal (4 vs $1 \mathrm{~g}$, respectively). Despite the same age (54 days) and similar liveweight $(16-17 \mathrm{~kg})$ at the beginning of the fattening period (Table 4) lambs receiving the concentrate with rapeseed oilmeal achieved significantly $(\mathrm{P}<0.05)$ lower daily weight gains $(290 \mathrm{~g})$ than those fed soyabean oilmeal $(325 \mathrm{~g})$. The intake of $\mathrm{CP}$ and $\mathrm{ME}$ per $\mathrm{kg}$ of liveweight gain from both the concentrates offered was similar (Table 5) and amounted to $649 \mathrm{~g}$ and $40.8 \mathrm{MJ}$, respectively for group I and $595 \mathrm{~g}$ and $35.9 \mathrm{MJ}$, respectively for group II. In both groups the relative cost of concentrate consumed per $\mathrm{kg}$ of weight gain was similar (I - 100 and II - 98\%).

TABIF 3

Intake of dry matter, nutrients and metabolizable energy, $\mathrm{g}$ and $\mathrm{MJ} / \mathrm{kg} \mathrm{W}^{0.75}$

\begin{tabular}{|c|c|c|c|c|c|c|c|c|}
\hline \multirow[b]{2}{*}{ Ingredients } & \multicolumn{2}{|c|}{ Group } & \multicolumn{2}{|c|}{ Sex } & \multicolumn{3}{|c|}{ Typc of birth } & \multirow[b]{2}{*}{ SEM } \\
\hline & I & II & males & females & 2 & 3 & 4 & \\
\hline Dry matter & 85 & 77 & 78 & 85 & 82 & 80 & 82 & 2.4 \\
\hline Organic matter & 79 & 73 & 73 & 79 & 77 & 75 & 76 & 2.3 \\
\hline Crude protein & 17 & 16 & 16 & 17 & 17 & 18 & 17 & 0.5 \\
\hline Crude fibre & $7^{A}$ & $5^{\mathrm{B}}$ & 6 & 6 & 6 & 6 & 6 & 0.2 \\
\hline Ether extract & $4^{\mathrm{A}}$ & $1^{\mathrm{B}}$ & 3 & 3 & 3 & 3 & 3 & 0.1 \\
\hline $\mathrm{N}$-free extractives & 50 & 51 & 48 & 53 & 51 & 50 & 51 & 1.5 \\
\hline NDF & $18:$ & $16^{\mathrm{h}}$ & 16 & 17 & 17 & 16 & 17 & 0.5 \\
\hline $\mathrm{ADF}$ & $10^{\mathrm{A}}$ & $7^{\mathrm{B}}$ & 8 & 8 & 8 & 8 & 8 & 0.3 \\
\hline ADL & $3^{A}$ & $1^{\mathrm{B}}$ & 2 & 2. & 2 & 2 & 2 & 0.1 \\
\hline ME, MJ & 1.1 & 1.0 & 1.0 & 1.1 & 1.0 & 1.0 & 1.0 & 0.03 \\
\hline
\end{tabular}

A. $-\mathrm{P}<0.05 ;$ A. B $-\mathrm{P}<0.01$

TABLE 4

Age, liveweight and liveweight gain of lambs

\begin{tabular}{|c|c|c|c|c|c|c|c|c|}
\hline \multirow[b]{2}{*}{ Indices } & \multicolumn{2}{|c|}{ Group } & \multicolumn{2}{|c|}{ Sex } & \multicolumn{3}{|c|}{ Type of birth } & \multirow[b]{2}{*}{ SEM } \\
\hline & I & 11 & males & females & 2 & 3 & 4 & \\
\hline \multicolumn{9}{|l|}{ Age, days } \\
\hline initial & 54 & 54 & 54 & 54 & 54 & 54 & 55 & 0.5 \\
\hline final & 118 & 113 & 114 & 117 & $114^{4}$ & $109^{\mathrm{A}}$ & $123^{\mathrm{hB}}$ & 1.8 \\
\hline Days of fattening & 64 & 59 & 60 & 63 & 60 & 55 & 68 & 1.8 \\
\hline \multicolumn{9}{|l|}{ Liveweight, $\mathrm{kg}$} \\
\hline initial & 17.1 & 16.0 & $15.5^{\prime \prime}$ & $17.6^{\mathrm{h}}$ & $15.6^{\mathrm{a}}$ & $18.5^{\mathrm{h}}$ & $15.6^{\circ}$ & 0.48 \\
\hline final & 35.2 & 34.8 & 35.2 & 34.8 & 35.4 & 34.9 & 34.7 & 0.17 \\
\hline daily gain, $\mathrm{g}$ & $290^{\prime \prime}$ & $325^{\mathrm{h}}$ & $335^{\wedge}$ & $280^{\mathrm{B}}$ & 332 & 305 & 285 & 8.2 \\
\hline
\end{tabular}


TABLE 5

Utilization of dry matter, nutrients and metabolizable energy, $\mathrm{g}$ and $\mathrm{MJ} / \mathrm{kg}$ gain

\begin{tabular}{|c|c|c|c|c|c|c|c|c|}
\hline \multirow[b]{2}{*}{ Indices } & \multicolumn{2}{|c|}{ Group } & \multicolumn{2}{|c|}{ Sex } & \multicolumn{3}{|c|}{ Ty pe of birth } & \multirow[b]{2}{*}{ SEM } \\
\hline & I & II & males & females & 2 & 3 & 4 & \\
\hline Dry matter & 3210 & 2874 & 2855 & 3230 & 3011 & 3096 & 3020 & 93.5 \\
\hline Organic matter & 2961 & 2711 & $2660^{\prime \prime}$ & $3011^{\mathrm{b}}$ & 2808 & 2886 & 2813 & 86.5 \\
\hline Crude protein & 649 & 595 & $583^{a}$ & $660^{\mathrm{h}}$ & 616 & 633 & 617 & 18.9 \\
\hline Crude fibre & $250^{\wedge}$ & $187^{\mathrm{B}}$ & 206 & 231 & 215 & 222 & 218 & 7.1 \\
\hline Ether cxtract & $166^{\mathrm{A}}$ & $49^{\mathrm{B}}$ & 103 & 112 & 102 & 109 & 111 & 4.5 \\
\hline $\mathrm{N}$-free extractives & 1896 & 1880 & $1768^{\circ}$ & $2008^{b}$ & 1875 & 1922 & 1867 & 56.2 \\
\hline $\mathrm{ME}, \mathrm{MJ}$ & 40.8 & 35.9 & 36.0 & 40.7 & 37.9 & 39.0 & 38.1 & 1.18 \\
\hline Cost of concentrates, $\%$ & 100 & 98 & & & & & & \\
\hline
\end{tabular}

a. h $-\mathrm{P}<0.05 ;$ A. B $-\mathrm{P}<0.01$

\section{DISSCUSION}

The concentrate feeds used in the present investigations were of a similar nutritional value and met the recommendations for intensive fattening of lambs (Ryś, 1996). As shown by other authors in experiments conducted on lambs (Pakulski and Osikowski, 1993), substituting soyabean oilmeal with rapeseed oilmeal had no detrimental effect on the palatability of the concentrate. During fattening, lambs from both groups consumed a similar quantity of DM when calculated per kilogram of metabolic body weight $\left(\mathrm{W}^{0.75}\right)$. Also, no significant differences were observed when analyzing the consumption of $\mathrm{CP}$ and $\mathrm{ME}$. In turn, the differences in the consumption of crude fibre, its fractions, and ether extract, observed in favour of lambs fed the concentrate with rapeseed oilmeal resulted from the mentioned difference in the content of those components in the concentrates tested. Lambs recciving the concentrate containing rapeseed oilmeal (the rapeseed oilmeal CP constituted about $48 \%$ of the total $\mathrm{CP}$ in the concentrate) had lower growth rate and their daily weight gains were about $10 \%$ lower than those of lambs fattened on the concentrate containing soyabean oilmeal (the soyabean oilmeal CP constituted about $41 \%$ of the total $\mathrm{CP}$ in the concentrate). Similar relations were reported by Potkański et al. (1991) in an experiment on lambs fattened with their dams from birth to 100 days of life. This negative reaction of suckling lambs to the total substitution of soyabean oilmeal by rapesced oilmeal ( $20 \%$ in the concentrate) was eliminated if about $10 \%$ of soyabean oilmeal was retained in the concentrate (Urbaniak and Potkański, 1991). When fattening older lambs (over three months old) the inclusion of 20-30\% of rapeseed oilmeal (Potkański et al., $1987 \mathrm{~b}$ ) or in a quantity introducing even $56 \%$ of total protein in the concentrate (Pakulski and Osikowski, 1993) did not negatively affect the fattening results (daily liveweight 
gains from $225 \mathrm{~g}$ to $250 \mathrm{~g}$ ). No significant differences were also observed in apparent digestibility and nitrogen retention between lambs fed concentrates containing rapeseed or soyabean oilmeal (Potkański et al., 1987 a). However, in another work (Żebrowska et al., 1991), in which the CP of rapeseed oilmeal constituted about $40 \%$ of the total $\mathrm{CP}$ in the dict, a significantly higher apparent digestibility was observed for the diet containing soyabean oilmeal as well as a gencrally higher nutritional value of the soyabean protein. The lower body weight gains obtained in the present investigations by lambs fed a concentrate with rapeseed oilmeal were probably caused by its poorer nutritional valuc and substitution of dried sugar beet pulp by oats. Similarly as in the investigations reported by Ringdorfer and Niżnikowski (1993), the concentrate containing rapeseed oilmeal ensured daily weight gains of about $300 \mathrm{~g}$. However, in other investigations conducted on the same flock (Janiuk et al., 1998), the three-breed lambs showed a greater potential for growth (over $350 \mathrm{~g} /$ day). Thus, in case of intensive fattening of lambs, where daily weight gains are expected to exceed $300 \mathrm{~g}$, feeding concentrates containing $25 \%$ of rapesecd oilmeal may mean poorer fattening results.

\section{REFERENCES}

Gwiazda S., Hanczakowski P.. Szymczyk B., 1996. Composition and nutritive value of waste preparations remaining after hydrolysis of double improved rapeseed meal (in Polish). Rocz. Nauk. Zoot. 23, 267.278

Harvey W.R., 1990. Mixed model least-squares and maximum likelihood computer program PC-2, Ohio State University

Janiuk W., Baranowski A., Klewice J., 1998. Performance and slaughter value of Polish Merino, Booroola and Suffolk crossbred lambs. J. Anim. Feed Sci. 7, 161-170

MAFF, 1975. Energy Allowances and Feeding System for Ruminants. London, Tech. Bull. No 33

Pakulski T., Osikowski M., 1993. Use of rapeseed „00" (seeds and extracted rapeseed meal) in fattening lambs (in Polish). Seminar on „Production of feeds from leguminous plants, grain and rapeseed and their use in animal nutrition". JUNG, Instytut Zootechniki, pp. 101-105

P’otkański A.. Urbaniak M., Michalak W., 1987a. Utilization of extracted rapeseed meal of low glucosinolate "Start 00 " variety in feeding merino lamb. I. Digestibility and nitrogen balance. Proceedings of the $7^{\text {th }}$ International Rapeseed Congress, Poznan (Poland), p. 1848

Potkański A., Urbaniak M., Michalak W., 1987b. Utilization of extracted rapeseed meal of low glucosinolate „Start 00 " variety in feeding Merino lamb. II. Performance of fattened lambs. Proceedings of the 7th International Rapesced Congress, Poznan (Poland) p. 1849

Potkański A., Urbaniak M., Kujawa $\Lambda ., 1991$. Utilization of post-extraction rapeseed meal to replace post-extraction soyabean meal in concentrates used in feeding suckling lambs (in Polish). Rocz. Akad. Rol. Poznań, CCXXVIII, Zoot. 41, 45-53

Ringưorfer F., Niżnikowski R., 1993. Einsatz von Erbse sowie Sonnenblumen- und Rapsextraktionsschrot als Eiweisskomponente in der Lämmermastration. Wirtschaftseig. Futter $39,215-227$ 
Ryś R., 1996. Nutrition Standards for Cattle and Sheep Traditionally Reared (in Polish). Inst. Zoot., Kraków (Poland)

Sionck B., Hanczakowski P., Dąbrowski K., 1994. Effect of different stages of processing of improved rapeseed meal on the content of the antinutritional substances and its nutritive value (in Polish). Rocz. Nauk. Zoot. 21, 239-245

Urbaniak M., Potkański A., 1991. Effect of rapeseed meal contained in CJ concentrate on weight gains of lambs and calves and on thyroxine and triiodothyronine in blood plasma (in Polish). Rocz. Akad. Rol. Poznań, 228, Zoot. 41, 37-44

Żebrowska H., Żebrowska T., Długołęcka Z., Pająk J., 1991. A comparison of the digestion of protein in the different section of the digestive tract of sheep fed on diets containing rapeseed meal or soyabean meal (in Polish). Rocz. Nauk. Zoot. Monogr. Rozpr. 29, 126-131

\section{STRESZCZENIE}

\section{Produkcyjność jagniąt-mieszańców intensywnie tuczonych mieszanką treściwą z udziałem poekstrakcyjnej śruty rzepakowej „OO”}

Dwie grupy ( $\mathrm{n}=30)$ jagniąt-mieszańców ( $25 \%$ merynos polski, $25 \%$ booroola i $50 \%$ suffolk) po odłączeniu od matck w wicku 8 tygodni intensywnic tuczono granulowanymi mieszankami treściwymi o zbliżoncj wartości pokarmowej (Grupa I - $202 \mathrm{~g}$ białka ogólnego (b.og.) $/ \mathrm{kg}$ suchej masy (sm) i $12.7 \mathrm{MJ}$ energii metabolicznej (EM)/kg sm; Grupa II -- $207 \mathrm{~g}$ b.og. $/ \mathrm{kg} \mathrm{sm} \mathrm{i} 12.5 \mathrm{MJ}$ EM $/ \mathrm{kg}$ $\mathrm{sm}$ ) do uzyskania masy ciała $35 \mathrm{~kg}$. W okresie tuczu jagnięta ( 8 tryczków i 7 maciorek w każdej grupic) żywiono do woli (indywidualna kontrola pobranych pasz treściwych) mieszanką treściwą z udziałem poekstrakcyjnej śruty sojowej i suszonych wysłodków buraczanych lub mieszanką treściwą, w której śrutę sojową i wysłodki zastąpiono poekstrakcyjną śntą rzepakową „00” (25\%) i ziarnem owsa. Jagnięta podczas tuczu pobrały w przeliczeniu na $1 \mathrm{~kg}$ metabolicznej masy ciała $\left(\mathrm{W}^{0.75}\right.$ ) zbliżoną ilość suchej masy, białka ogólnego i cnergii metaboliczncj (Grupa I - odpowiednio $85 \mathrm{~g}, 17 \mathrm{~g} \mathrm{i} 1.1 \mathrm{MJ}$; Grupa II odpowiednio $77 \mathrm{~g}, 16 \mathrm{~g}$ i $1.0 \mathrm{MJ}$ ) niezależnie od rodzaju skarmianej paszy treściwej. Dobowe przyrosty jagniąt żywionych mieszanką treściwą z $25 \%$ udziałem śruty rzepakowej $(290 \mathrm{~g})$ były istotnic $(\mathrm{P} \leq 0.05)$ niższe niż przyrosty jagniąt otrzymujących micszankę ze śrutą sojową ( $325 \mathrm{~g})$. Typ urodzenia nie miał istotnego wpływu na wyniki tuczu.

Koszt paszy treściwej potrzcbnej do wyprodukowania $1 \mathrm{~kg}$ żywca był zbliżony w obydwóch grupach jagniąt. 